Boudewijn J. Smits ${ }^{1}$

\title{
ZWIJGEN EN SPREKEN IN DE AFFAIRE-AANTJES
}

'Aantjes meldde zich in I944 bij de ss,' luidde de primeur over de CDA-fractieleider in het Nieuwsblad van het Noorden op maandag 6 november 1978. Het spectaculaire nieuws bereikte het Nederlandse publiek die middag opvallend traag. Pas door de persconferentie van dr. L. de Jong, de directeur van het Rijksinstituut voor Oorlogsdocumentatie (RIOD), die's avonds op prime time live werd uitgezonden op de televisie, raakten miljoenen kijkers op de hoogte.

De Jong verklaarde dat Aantjes in I944 door de Waffen-ss was gemobiliseerd. Vervolgens was hij als kampbewaarder in strafkamp Port Natal in Assen tewerkgesteld. Loe de Jong, die gewaardeerd werd door zijn zakelijke presentatie, toonde zich bij vlagen emotioneel. Hij schamperde dat, vanwege veronderstelde dienstneming bij een vijandelijk leger, niet uitgesloten was 'dat wij bijna twintig jaar lang een Kamerlid hebben gehad - en op het ogenblik nog hebben de fractievoorzitter van de grootste regeringsfractie, die niet eens Nederlander is!' Die avond keerde de publieke opinie zich in een golf van verontwaardiging en masse tegen Willem Aantjes. Dinsdagmiddag trok de CDA-fractievoorzitter zich terug uit de politiek. Zijn politieke val was abrupt, diep en definitief.

Dit artikel gaat over het schokeffect in de publieke meningsvorming waarmee de affaire werd ingeluid die behoort tot de meest geruchtmakende mediaschandalen in de naoorlogse Nederlandse politiek. Het Nederlandse publiek werd dubbel verrast. De aandacht richtte zich als een magneet op de letters 'ss'. Aantjes stelde de toedracht die volgende dag echter in een ander daglicht. Hieronder wordt ingegaan op de vraag hoe het mogelijk was dat de gerenommeerde wetenschapper De Jong die televisieavond als vrijwel enige opinion leader optrad, terwijl hij slechts een mager onderzoeksverslag met een aantal voorlopige veronderstellingen over Aantjes' belaste bezettingsverleden kon presenteren.

Daarnaast werd dit verrassingselement versterkt doordat op die televisieavond duidelijk werd aan het Nederlandse publiek dat het bezettingsverleden van Aantjes in besloten kring jarenlang al vagelijk bekend was geweest. Daarom zal eerst worden verklaard waarom in de aanloop tot de persconferentie van 6 november 1978 de verhalen over het gedrag van deze ARP-politicus tijdens de oorlog twee decennia lang wel in een geruchtencircuit rouleerden, maar niet in de pers kwamen. 


\section{Onjuiste feiten, discutabele veronderstellingen en nieuwe feiten}

Op dinsdagmiddag 7 november deed Aantjes met onmiddellijke ingang afstand van zijn politieke functies. De perszaal van Nieuwspoort was, net als bij De Jong die vorige avond, afgeladen vol. In zijn repliek riep Aantjes 'een wezenlijk ander beeld' op dan uit het RIOD-rapport naar voren kwam. 'Ik ben niet fout geweest. Ik heb fouten gemaakt.' Wilskrachtig liet hij erop volgen dat hij 'niet voornemens (was) om onweersproken te laten wat er op tafel ligt'. Aansluitend hield waarnemend CDA-fractievoorzitter, Ruud Lubbers, een pleidooi voor het 'recht van wederwoord'. ${ }^{2}$ Ditmaal werd de persconferentie rechtstreeks via de radio uitgezonden. Om drie uur verschenen de eerste beelden op televisie en om zes uur volgde een integrale uitzending. Met de journaals meegerekend kwam de persconferentie van Aantjes op deze tweede avond van het schandaal vijf keer op het scherm. ${ }^{3}$

In de loop van die week kwamen diverse complottheorieën tot ontwikkeling. ${ }^{4}$ Aantjes zou beentje zijn gelicht door rechtse krachten uit overwegend katholieke hoek, die niet gediend waren van deze fractievoorzitter die behoorde tot de linkse CDA-loyalisten. Anderen meenden dat de ondermijning juist van linkse zijde kwam, omdat Aantjes begin november 1977 de formatie van een tweede socialistisch-confessioneel kabinet-Den Uyl op de valreep zou hebben geblokkeerd.

Tweede-Kamervoorzitter Anne Vondeling kanaliseerde de maatschappelijke discussie naar het politieke domein. In een Kamerdebat op donderdag I6 november 1978 moest de regering zich verantwoorden voor de gevolgde procedure. Waarom had de directeur van het Rijksinstituut voor Oorlogsdocumentatie zijn onderzoek zo snel in de publiciteit gebracht, terwijl aan veel van zijn feiten en veronderstellingen werd getwijfeld?

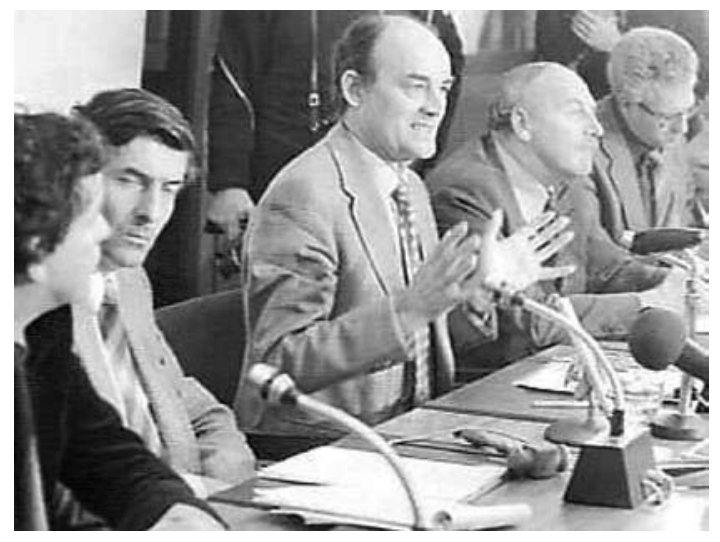

Willem Aantjes tijdens zijn persconferentie op 7 november 1978 , waarin hij zijn vertrek uit de politiek toelicht. Geflankeerd door CDA-partijgenoten Ruud Lubbers (l) en Maarten Schakel (r). Bron: Beeldbank Nationaal Archief, Anefo/Croes

Tijdens het debat bleek dat het kabinet-Van Agt, net als het grote publiek, ook was overrompeld door de onverwacht snelle berichtgeving van het Nieuwsblad van het Noorden. Het confessioneel-liberale meerderheidskabinet-Van Agt-Wiegel werd door de grootste oppositiepartij, de PvdA, met in haar kielzog de drie kleine linkse partijen D66, PPR en PSP, echter geen moment aan het wankelen gebracht. De vvD oordeelde mild en het CDA kritisch, maar beide regeringspartijen vonden niet dat het kabinet verwijtbaar verkeerd had gehandeld.

Diteerste debatleidde totveelvragen, waarop de regering het antwoord schuldig moest blijven. Eind november 1978 besloot de Bij- 
zondere Kamercommissie twee onafhankelijke onderzoekscommissies in te stellen, die bekend werden onder de naam van hun voorzitters: Ch.J Enschedé en PvdA-Kamerlid mr. S. Patijn. Een half jaar later presenteerden zij hun eindrapporten gelijktijdig. Op 29 en 30 augustus 1979 volgde het afsluitende Kamerdebat.

De Commissie-Enschedé, bestaande uit drie onafhankelijke specialisten, verdiepte zich in Aantjes' oorlogsgedragingen. In haar eindrapport corrigeerde deze Commissie van Drie het RIOD-rapport op een aantal essentiële punten. ${ }^{5}$ Aantjes had zich aan zijn Arbeitseinsatz in Güstrow, waar hij als postbeambte was gestationeerd, willen onttrekken door zich bij de Germaanse-ss aan te melden. Op I2 oktober I944 werd hij door de Waffen-ss naar Nederland getransporteerd voor een opleiding bij de Landstorm tot grensbewaker. Eenmaal in Hoogeveen gearriveerd, weigerde Aantjes dienst. Vervolgens werd hij als gevangene in Kamp Port Natal geïnterneerd, waar hij na enige tijd bewakingsdiensten vervulde. Aangezien Aantjes niet in vreemde krijgs- of staatsdienst was getreden, was er geen sprake van dat hij zijn Nederlanderschap had verloren.

\section{Wel of geen complot?}

De tweede onderzoekscommissie bestond uit vijf Kamerleden onder voorzitterschap van de PvdA-er Schelto Patijn. ${ }^{6}$ Uit haar eindrapport bleek dat Aanties zijn vlucht via de ss bewust en stelselmatig had verzwegen. Eveneens werd geconcludeerd dat 'voor zover zij heeft kunnen nagaan', er op geen enkele manier sprake was geweest van een gecoördineerd politiek complot op staatsniveau. Patijn was hier persoonlijk al na enkele weken van onderzoek van overtuigd geraakt. In het afsluitende Kamerdebat onderstreepte hij nogmaals dat van een complot om Aantjes 'kapot te maken' geen deugdelijk bewijs was verkregen.7 Daarna heeft hij geen signalen meer opgevangen dat zijn weerlegging van de complottheorie voorbarig was geweest. ${ }^{8}$

De linkse partijen hadden voor deze Kamercommissie de enquête-bevoegdheid willen opeisen, maar de regeringspartijen hadden dit middel te zwaar bevonden. De getuigen waren dus niet verplicht te verschijnen en evenmin stonden zij onder ede, zodat zij niet verplicht waren alle vragen te beantwoorden. Volgens Patijn was deze beperkte bevoegdheid in de praktijk geen bezwaar. Wiert P. Berghuis, de voormalige AR-partijvoorzitter, deed aanvankelijk een beroep op zijn hoge leeftijd om niet te hoeven verschijnen. Toen Patijn echter aanbood dan met de gehele commissie bij hem thuis op bezoek te willen komen, verkoos hij om zich per taxi naar het Binnenhof te laten rijden. Eef Brouwers en Kees Wiese, respectievelijk de hoofd- en voormalig parlementair redacteur van het Nieuwsblad van het Noorden, zwegen selectief. Brouwers wilde niet meer kwijt dan dat het nieuws voortkwam 'uit eigen nieuwsgaring'. Hij liet weten onder ede te zullen blijven volharden in zijn verschoningsrecht, op grond 
waarvan hij de identiteit van zijn bron niet behoefde vrij te geven. ${ }^{9}$ Wiese zei de bron niet te kennen en beroepsmatig niet te willen weten. De gouden tip die tot de primeur had geleid, zou ook onder ede niet zijn onthuld.

Daarnaast was er een aantal advocaten dat, ook na lang doorvragen door de commissieleden, bezwoer onderling geen contact te hebben gehad. ${ }^{\text {10 }} \mathrm{Hun}$ categorische ontkenningen overtuigden niet volledig. Tot hen behoorden Iwan E. Hes uit Den Haag en Henk J.P. Dolk uit Amsterdam, die eind oktober 1978 vrijwel gelijktijdig De Jong hadden getipt over het besmette oorlogsverleden van Aantjes. Op basis van hun tips had De Jong als RIOD-directeur zijn oriënterend onderzoek ingesteld. Advocaat Henk en zijn broer en vennoot, Gerard A. J. Dolk, hadden beiden met Aantjes op het Marnix College in Rotterdam gezeten. Gerard Dolk, die ook als informant in het onderzoek van De Jong was betrokken, wierp elke verdachtmaking van zich af door op I5 november 1978 een open brief aan de Kamervoorzitter te richten. Hij was ervan overtuigd dat in de publieke opinie

'de aandacht van de hoofdzaak, te weten de vraag of de Heer Aantjes gedurende de Tweede Wereldoorlog heeft gefaald, en kans heeft gezien zulks door leugens en bedrog voor het Nederlandse volk verborgen te houden, wordt afgeleid door te zoeken naar een mogelijk complot om de heer Aantjes in moeilijkheden te brengen.'

Hij vond het juist prijzenswaardig dat enkele burgers bereid waren geweest om misstanden uit de wereld te helpen. ${ }^{\text {II }}$

Ook de journalist Thomas Lepeltak (alias Stan Huygens) van De Telegraafliet zich niet onbetuigd. Op maandag 29 oktober 1978 , dezelfde middag dat De Jong sprak met Henk Dolk als eerste stap in zijn geheime onderzoek, lunchte Lepeltak in een Haags etablissement met een tafelgenoot die hem toevertrouwde dat De Jong van Oorlogsdocumentatie in opdracht van de regering een onderzoek was begonnen naar het oorlogsverleden van Aantjes. Lepeltak wilde hier in 2007 nog wel aan toevoegen dat dit een CDA-politicus was geweest. ${ }^{12}$ Het voorval doet nogal fantastisch aan. De regering was op dat moment nog onwetend over het antecedentenonderzoek van De Jong. En welk belang kon een partijgenoot hebben om dit nieuws te laten uitlekken? De Telegraaf had erop gezinspeeld dat het lek van ARP-er Jan Nico Scholten afkomstig was. ${ }^{13}$ Tussen hem en Aantjes boterde het niet. Lepeltak legde de tip nog diezelfde middag voor aan zijn hoofdredacteur, Goeman Borgesius. Deze hechtte weinig waarde aan het 'postbodeverhaal' dat in Den Haag al zo lang over Aantjes rouleerde. Later betreurde hij het als de grootste journalistieke fout in zijn carrière dat hij de scoop van het jaar had laten passeren. ${ }^{\mathrm{I}}$

$\mathrm{Na}$ het eindrapport van de Commissie-Patijn is de geruchtenstroom over een complot wel geluwd, maar nooit geheel verdwenen. De journalist Henk Hofland vestigde in het VPRO-radioprogramma WELINGELICHTE KRINGEN de 
aandacht op de vrije ruimte die ontstaat door van een toevallige samenloop van omstandigheden handig gebruik te maken. 'Er is een continuüm tussen totale samenzwering te kwader trouw en een toevallige samenloop van omstandigheden die ten eigen voordele door machthebbers gebruikt kan worden.' ${ }^{15}$ Ook de Kamerleden toonden zich niet in alle opzichten gerustgesteld door de weliswaar plausibele, maar niet keihard te bewijzen conclusie van Patijn. Mevrouw Elida Wessel-Tuinstra, de woordvoerster van D66, die ook commissielid was, gaf in het slotdebat een andere betekenis aan het begrip complot. ${ }^{16}$ Er was wel degelijk een politiek complot rondom Aantjes geweest, betoogde ze, 'een complot van stilzwijgen. Aan deze samenspanning hebben vooraanstaande politici meegedaan. Zij hebben feiten verzwegen, niet alleen voor de eigen partij, maar voor het Nederlandse kiezersvolk en daarmee ons democratisch bestel schade berokkend.' ${ }^{\text {T7 }}$ Hoe steekhoudend was haar opmerking?

Complotteren, het smeden van een geheime samenzwering, is een begrip dat bij uitstek paste in de mediahype die na 6 november 1978 losbarstte. De veronderstelling van een complot veronderstelt onderlinge geheime afspraken en een nauwgezet draaiboek. Omvangrijk onderzoek door twee commissies, langdurige pogingen tot waarheidsvinding in de pers en nauwgezet promotieonderzoek van Roelof Bouwman, die in 2002 een politieke biografie over Aantjes publiceerde, hebben hier geen enkel bewijs voor op tafel kunnen leggen.

Zoveel is wel duidelijk: aan de affaire-Aantjes ging geen complot vooraf. Er was wel sprake van een jarenlange strijd tussen zwijgers en sprekers. Het verzwegen geheim van Aantjes riep bij enkelen als tegenreactie op dat de waarheid aan het licht diende te komen. Er was een actie-reactie patroon van individuele burgers, die incidenteel op elkaar inwerkten door informatie te verstrekken of juist achter te houden, of door uitlatingen in besloten kring te doen of juist na te laten. Medestanders speelden elkaar soms de bal toe zonder dat er een complot volgens uitgewerkt scenario aan ten grondslag lag. Dit mechanisme van zwijgen en spreken vertoont overeenkomst met de dynamiek van het figuratiemodel dat Norbert Elias ontwikkelde. De socioloog analyseert het civilisatieproces als de uitkomst van een complexe vervlechting van individuele handelingen en gedragingen, waarbij de enkeling de uitkomst van zijn eigen inspanningen niet kan voorspellen. ${ }^{18}$

In de strijd ging het om verzwijging, dan wel onthulling van het belastende oorlogsverleden van Aantjes met de bedoeling voortzetting, dan wel beëindiging van zijn politieke carrière. De belangrijkste spelers waren enerzijds de politicus Willem Aantjes en de ARP-top en anderzijds, vanaf medio jaren zestig, de advocaat Henk Dolk en, vanaf eind oktober 1978, de historicus Loe de Jong. Onderling werden speldenprikken en schimpscheuten uitgedeeld. Betrokkenen vertoonden gedrag waarbij steunen en afvallen, beschermen en beschadigen, misleiden en stoken, oprechte intenties en bedrog in verschillende gradaties voorkwamen. In dit ondoorzichtige spel botsten morele overtuigingen. Het 
is niet toevallig dat dit schandaal door tijdgenoten bij herhaling werd vergeleken met een Shakespeareaans drama of Kafkaiaanse intrige. ${ }^{19}$ Waarom heeft de pers hier niet eerder dan op 6 november 1978 verslag van gedaan?

De verklaring voor deze stille en lange voorgeschiedenis is gelegen in de politieke en journalistieke cultuur van het naoorlogse Nederland. In de eerste jaren na de bevrijding werd afgerekend met collaborateurs en politieke delinquenten uit de bezettingsperiode. Het motto 'snel, streng en rechtvaardig' klonk krachtdadig, maar de werkelijkheid was weerbarstig. De maatschappelijke vernieuwing mislukte schromelijk. In de jaren vijftig was de persoonlijke herinnering aan de gruwelijke bezettingsperiode vooral een verdrongen aangelegenheid. Alle aandacht en energie ging uit naar de wederopbouw. De hokjesgeest van de verzuilde vooroorlogse maatschappij bloeide uitbundiger dan ooit tevoren. Eind jaren vijftig kon het gebeuren dat politici wier gedrag in de bezettingstijd bepaald niet onbesproken was, toetraden tot de regering. Het bekendste voorbeeld is de Kvp'er Jan E. de Quay, een van de drie leiders van de Nederlandse Unie, die premier (1959-1963) werd van een kabinet waarin ook de ARP deelnam.

De biograaf van Aantjes kon niet reconstrueren in hoeverre de toenmalige vice-voorzitter, Jan Smallenbroek, en de Trouw hoofdredacteur en fractievoorzitter J.A.H.J.S. Bruins Slot - beide vooraanstaande verzetslieden - bij de kandidaatsstelling van Aantjes als Tweede-Kamerlid in 1955/'56 weet hadden van Aantjes' opstelling tijdens de bezetting. Onder antirevolutionairen was het courant dat zij die 'goed' waren geweest zich bevoegd achtten mild te oordelen over de eventuele misstappen van de leden. ${ }^{20}$

In het eerste decennium sinds de beëdiging van Aantjes als Kamerlid op 26 mei 1959, bleef het spreken over zijn gedrag in de oorlog beperkt tot een enkel incident. Zo ontving de AR-krant Trouw in I966 een ingezonden brief van oud-klasgenoot Piet Los over de pro-Duitse gezindheid van Aantjes in de eerste oorlogsjaren, die echter als querulantenpost opzij werd geschoven. ${ }^{2 \mathrm{I}}$ Aantjes' politieke carrière werd pas nadrukkelijk geblokkeerd bij de formatie van het confessioneel-liberale kabinet van Piet de Jong in maart I967.

\section{De demarcatielijn van 1967}

Na een decennium van bewezen diensten in het Kamerwerk, werd Aantjes door de AR-top ministeriabel geacht. Partijvoorzitter Berghuis was door de hem onbekende Henk Dolk in november I 966 al eens benaderd over verdacht gedrag van Aantjes in de bezettingstijd. Toen in het nieuws kwam dat formateur Piet de Jong Aantjes de ministerspost Volkshuisvesting had aangeboden, waarschuwde Henk Dolk zijn oud-schoolgenoot in een telegram dat hij niet zou dralen om de toekomstige minister-president over het besmette oorlogsverleden van zijn kandidaat-minister te verwittigen. ${ }^{22}$ 


\section{DRIJFZAND}

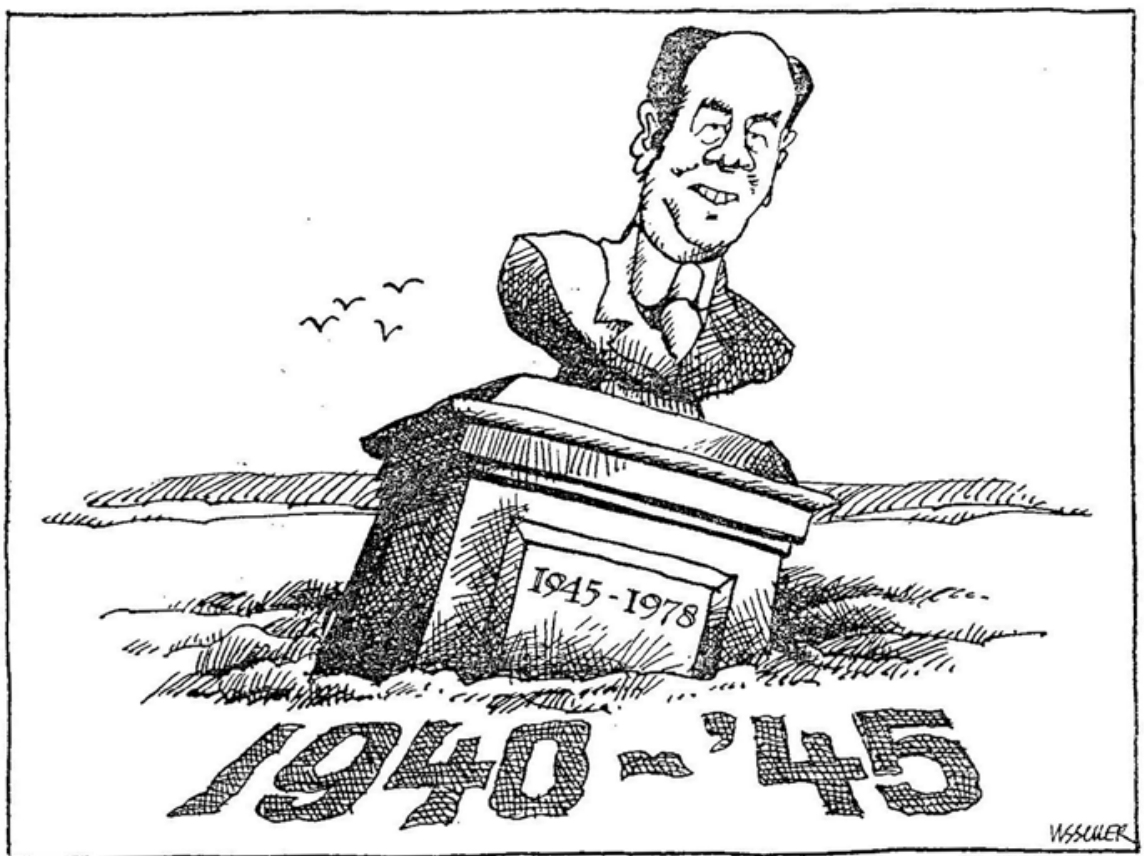

Prent van Nico Visscher in het Nieuwsblad van het Noorden 11 november 1978

Op vrijdag 3I maart I967 volgden de ontwikkelingen elkaar in hoog tempo op. Berghuis werd die ochtend thuis in Kampen gebeld door een partijgenoot, Berend ter Veen, die hem dringend liet weten dat Aantjes in de oorlog 'volkomen fout was geweest'. Hij kondigde aan, Berghuis die middag een getuigenis van zijn informanten op schrift af te zullen leveren.

Berghuis belde hierover even na elf uur met zijn fractievoorzitter, Barend Biesheuvel, die zojuist aan de formateur had laten weten dat de kandidatuur van Aantjes namens de ARP akkoord was. Zij waren het onderling snel eens. Biesheuvel belde de formateur om kwart over elf opnieuw, ditmaal met de boodschap dat hij het ongewenst vond dat Aantjes zou toetreden tot het nieuwe kabinet. De aankomende premier vond het niet passend om zich nader te informeren over de interne partijoverwegingen voor deze plotse koerswijziging. Vervolgens verzocht fractievoorzitter Biesheuvel Kamerlid Aantjes om partijvoorzitter Berghuis te bellen over 'iets dat in de oorlog gespeeld heeft'.

Om half twee kreeg Berghuis de verklaring thuisbezorgd van twee kampgenoten uit Port Natal, Jantienus Mastebroek en Arie Weites. Hierin las hij dat Aantjes lid was geweest van de Germaanse-ss. ${ }^{23}$ De getuigen hadden besloten hun stem te verheffen, omdat zij het niet met hun geweten konden verenigen als de ss'er Aantjes direct onder de Kroon, dus benoemd door de Koningin, zou dienen. Toen Berghuis Aantjes telefonisch met dit feit confronteerde, gaf Aantjes te kennen dat zijn oorlogsverleden 'niet helemaal brandschoon was', maar 
hij bestreed dat hij deel had uitgemaakt van de Germaanse-ss. Berghuis benadrukte dat Aantjes 'wel heel erg sterk in zijn schoenen moest staan, wilde hij het Ministerschap aanvaarden. ${ }^{24}$ De partijleider bood Aantjes de gelegenheid de eer aan zichzelf te houden. Na overleg met zijn huisarts en voormalige psychiater liet Aantjes zijn fractieleider weten van het ministerschap af te zien.

Aantjes liet de formateur om I8.20 uur weten dat hij zijn kandidatuur introk. ${ }^{25}$ Het AN P meldde dat Aantjes om 'politieke redenen geen bezwaar' had tegen een benoeming, maar dat hij 'om strikt persoonlijke redenen' had besloten van een ministerspost af te zien. 'Het is vrijwel zeker, dat deze persoonlijke redenen ten nauwste samenhangen met de gezondheid van mr. Aantjes,' zo werd eraan toegevoegd. Aantjes had zich neergelegd bij het feit dat het ministerschap geen haalbare kaart was in zijn verdere politieke loopbaan. Biesheuvel beschouwde het oorlogsverleden van zijn fractiegenoot als een privéaangelegenheid welke voor zijn Kamerlidmaatschap geen gevolgen had. De fractieleden kregen geen verdere toelichting. ${ }^{26}$ Niemand binnen de ARP was erop uit om de partij schade te berokkenen. Dolk, op zijn beurt, meende tevreden te mogen vaststellen dat zijn telegram het gewenste resultaat had opgeleverd. ${ }^{27}$

Berghuis verzocht Aantjes zijn oorlogsverleden volledig aan het papier toe te vertrouwen, waarbij hij er op aandrong nader in te gaan op zijn mogelijk lidmaatschap van de Germaanse-ss. In Aantjes' vertrouwelijke brief van I2 juni I967 werd een rechtstreeks antwoord op deze confronterende vraag omzeild. Aantjes lichtte in 2007 toe dat hij daar vanaf had gezien, omdat je nooit weet waar die schriftelijke informatie terecht komt en wie het leest. Zijn vlucht met de ss als ontsnappingsroute had hij wel degelijk met Berghuis vertrouwelijk besproken. Bovendien is hij er altijd van overtuigd geweest dat zijn prominente partijgenoot Jan Smallenbroek tijdens diens politieke carrière van zijn oorlogsverleden had afgeweten. ${ }^{28}$

Berghuis noteerde voor zijn secretaresse in de kantlijn: 'Hartelijk dank, voor mij is daarmee de kous af - hij blijft dus politiek kwetsbaar - mijns inziens nu maar op zijn beloop laten - afschrift zenden aan Barend en Joop maar ook aan Jan Sm. en S. Br. Slot.' Deze vier personen: fractieleider Biesheuvel, partijsecretaris drs. Joop A. Bakker en de twee voormalige fractieleiders, Smallenbroek en Bruins Slot, bij wie Berghuis al in een eerder stadium over deze zaak had gesondeerd, hebben een kopie van deze brief echter nooit onder ogen gekregen. Berghuis leek het bij nader inzien verstandiger om deze heikele zaak 'onder zich te houden' in de hoop er nu definitief een streep onder te kunnen zetten. Hij lichtte zijn mannenbroeders mondeling in. ${ }^{29}$ Niemand in Den Haag, behalve Aantjes en Berghuis onderling, had het heikele ss-woord in de mond hoeven nemen. $3^{\circ}$ Aantjes en de partij waren gespaard en de gelederen sloten zich.

Uit de eufemistische manier waarop binnen de ARP over dit incident werd gesproken, blijkt dat deze oplossing werd 'begrepen'. Zo kreeg een vakkundig Trouw-redacteur als Ben van Kaam, die secretaris van de hoofdredactie was, te verstaan dat Aantjes in de oorlog van 'een' Duitse militaire organisatie lid was 
geweest, maar niet 'zo'n enge' en dat Aantjes daarmee niet anders dan een 'stommiteit', een 'jeugd-misstap' had begaan. Een gereformeerd journalist had aan een half woord voldoende. AR-senator De Gaay Fortman vond het weliswaar geen 'fraaie oplossing', maar ook hij zag geen reden om een einde aan het politieke leven te maken van iemand die verdiensten had en een zekere positie in de Kamer had opgebouwd. ${ }^{3}$ Deze reactie past nog geheel in de traditie van het 'interlocking directorate' tussen het 'richtingblad' Trouw en de Anti-Revolutionaire Partij. Deze zuilgebonden pers zou binnen enkele jaren uit de politieke en journalistieke cultuur verdwijnen. ${ }^{32}$

De heftige botsing in de zwijg-spreek spiraal mondde in maart I967 uit in een staakt het vuren. De demarcatielijn die achter de schermen tot stand kwam, bestendigde de status quo van Aantjes: wél Kamerlid, géén minister. Deze curieuze beperking van de politieke speelruimte van Aantjes, die indruist tegen de democratisch parlementaire spelregels, was de resultante van het streven binnen de partijtop om een politieke rel te voorkomen en een veelbelovend en ambitieus talent voor de fractie te behouden. Een harde voorwaarde voor het succes van deze geheime oplossing, die al doende tot stand kwam, was dat deze zaak niet meer zou worden opgerakeld. In I978 constateerden zijn critici dat hij destijds door zijn partijgenoten was gesauveerd. 33 Tien jaar eerder werd deze schikking binnen de ARP-top als legitiem ervaren.

\section{Het mechanisme van zwijgen en spreken na 1967}

Achter deze nogal arbitraire grens groeide Aantjes in de jaren zeventig uit tot succesvol politicus. Liefst drie maal werd hij door parlementaire journalisten uitgeroepen tot politicus van het jaar. In populariteit werd hij alleen overtroffen door Joop den Uyl. Aantjes werd recordhouder voorkeurstemmen. Toen CDAlijsttrekker Van Agt op ig december I977 aantrad als premier, volgde Aantjes hem op als fractievoorzitter. Nu de politieke ster van Aantjes was gestegen, bleek dat hij in een politieke fuik was gezwommen. De commotie rond de Drie van Breda in I972 leerde Aantjes dat een coming-out van 'zijn echte verhaal met de letters ss erbij' geen haalbare kaart was. ${ }^{34}$ De man die vanuit roeping de politiek als vak bedreef, heeft een geruisloos vertrek uit de politiek nooit overwogen. ${ }^{35}$

Terwijl het selectieve zwijgen van het Kamerlid Aantjes in het eerste decennium tot I967 nauwelijks tegengeluiden opriep, nam in het resterende decennium tot de ontknoping in I978 de druk om te spreken aanzienlijk toe. Advocaten als Henk Dolk en Piet Los zwengelden het geruchtencircuit weer aan zodra de naam van Aantjes voor een post als minister of Commissaris van de Koningin in Zeeland werd genoemd.

Het ligt ook in de verwachting dat door de aanzwellende trend van democratisering het belastende oorlogsverleden van Aantjes niet geëxcuseerd zou worden. Sinds de jaren zestig verliep de expansie van de economie en de moderni- 
sering de maatschappij geheel buiten het desintegrerende zuilensysteem om..$^{6}$ Hoe kon deze typisch verzuilde oplossing van maart 1967 de 'maalstroom van de ontzuiling' nog elf jaar lang te trotseren?

Bouwman spreekt over het 'gigantische raadsel van journalistieke laksheid' in het tijdvak van de jaren zeventig. ${ }^{37}$ In de affaire-Aantjes lijkt onwennigheid een passender karakterisering van het geleidelijke proces waarin het 'verzuilde gedrag' met de oude loyaliteitsbanden in de journalistiek werd geslecht. Dit gold zowel voor de journalisten als voor hun informanten. Illustratief is de opstelling van een parlementair verslaggever als Harry van Wijnen. Hij was een gerespecteerde en kritische Parool-journalist van protestants-christelijken huize, die zijn aandeel leverde in wat hij later noemde 'kleedkamerjournalistiek. Ook hij verlevendigde de journalistiek met het becommentariëren van incidenten en achtergronden en hij vertoefde op vertrouwelijke voet met vele politici, waaronder Aantjes. ${ }^{38}$

Medio 197I legden Van Wijnen en Pierre van Enk, zijn Trouw-collega, na een telefonische hint van Henk Dolk aan de toenmalige AR-partijvoorzitter, A. Veerman, het gerucht voor dat Aantjes mogelijk NsB-er was geweest. Veerman raadpleegde de briefwisseling uit I967 niet, maar beriep zich op zijn voorganger Berghuis die de geruchten al eens had uitgezocht en niets steekhoudends had vastgesteld. De waarheidsvinding van Van Wijnen ketste af. Hij meende dat het hier om lasterpraat ging, 'een akkefietje van gymnasiasten onder elkaar'. 39

Toen Van Wijnen bij Aantjes zelf tot twee- of driemaal toe zijn vermeende NSB-lidmaatschap ter sprake bracht, wees de politicus in kwestie deze geruchten stellig van de hand. Van Wijnen gaf achteraf te kennen dat hij een 'zekere gêne' koesterde om 'in dat potje te roeren' en hij verzuimde om door te vragen naar het partijonderzoek dat Berghuis destijds had laten uitvoeren..$^{40}$ Als journalist conformeerde hij zich aan de vertrouwensregels dat een politicus het recht heeft om eventueel leed, opgelopen in oorlogstijd, in de privésfeer te houden.

Rond februari-maart I975 legde Van Wijnen zijn vraag voor aan het hoofd van het Documentatiecentrum voor het Nederlands Historisch Protestantisme van de Vrije Universiteit. Dr. George Puchinger had de naam de grootste kenner van de geschiedenis van de protestants-christelijke politiek te zijn. Met een beroep op zijn gezag, gaf Puchinger te kennen niets over een fout oorlogsverleden van Aantijes te weten. Later lichtte hij toe dat zijn stellige ontkenning gespeend was van kennis van zaken. Het was een vanzelfsprekende reactie geweest om zijn geestverwant te beschermen tegen journalistieke opdringerigheid.4 ${ }^{4}$

Bouwman voert een drietal redenen aan waarom al die jaren het zwijgen de overhand over het spreken wist te behouden. Men was totaal niet bedacht op een besmet oorlogsverleden van leidende politici binnen de ARP. Samen met de CPN bezette de ARP een ereplaats in de galerij van politieke partijen met een moedig verzetsverleden. Bovendien genoot Aantjes een grote sympathie als politicus. Ten tweede was ook een deel van de progressievere katholieke CDA-aanhang gevoelig voor de manier waarop Aantjes het evangelie als inspiratiebron han- 
teerde. Daarbij diende zijn persoonlijke integriteit als waarmerk, al was deze reputatie in de beleving van Aantjes tot een selffulfilling prophecy geworden. Als hij zijn oprechtheid relativeerde, was steevast de reactie van de journalist dat hij door die zelfkritiek zijn eerlijkheid nu juist bewees..$^{22}$

Het progressieve tegengeluid dat Aantjes vertolkte in het CDA dat niet voor een linkse koers koos, ondersteunt ook de derde reden. Het (door veel journalisten bewonderde) kabinet-Den Uyl (I973-I977) was mede mogelijk geworden door de linkse koers van de ARP, geleid door de christendemocraat Aantjes. In de gepolariseerde jaren zeventig werd hij beschouwd als de 'lieveling van de socialisten'. Links Nederland herkende in hem een medestander, waar voorzichtig mee moest worden omgegaan.

Ook bij de RIOD-staf leefde geen enkele achterdocht over een eventueel oorlogsverleden van Aantjes. Voor journalisten lag het toch het meest voor de hand om eventuele twijfel over zijn aanmelding voor 'zekere politiediensten', zoals Aantjes vanaf I975 in interviews zijn aanmelding via de ss in eufemistische bewoordingen was gaan benoemen, nader te onderzoeken via Oorlogsdocumentatie - dat hiervoor bij uitstek was toegerust. Het RIOD was onafhankelijk van signatuur, maar werd tot het linkse kamp gerekend, al werd het in de maatschappelijk bewogen jaren zestig, begin jaren zeventig zeker niet tot de vooruitgeschoven posten gerekend. Directeur De Jong was weliswaar PvdA-er, maar eentje van de ouderwets conservatieve stempel. En in de affaire-Weinreb liepen de politiek linkse voorstanders die het eerherstel van de 'Jodenredder' nastreefden, dood op de ontnuchterende conclusies van het RIOD-rapport van 5 oktober 1976 waarin onomstotelijk werd vastgesteld dat Weinreb zich in oorlogstijd ernstig had misdragen.43

De Jong bleef tot eind oktober 1978 onwetend over een eventueel oorlogsverleden van Aantjes. Eenmaal getipt, toonde hij zich het meest geschokt over de stellige bewering van Henk Dolk dat Aantjes zich in maart I 967 voor een ministerspost had teruggetrokken om te voorkomen dat zijn bezettingverleden in de openbaarheid zou komen. Wanneer een politiek talent als Aantjes hiertoe besluit 'dan kan dat niet gaan om onbenullige kleinigheden, maar dan moet er iets werkelijk belastends zijn.' De Jong nam aanstoot aan onvaderlandslievend gedrag en dat stak des te meer als het een politicus betrof die een voorbeeldfunctie behoorde te vervullen. Het was voor hem ondenkbaar dat Aantjes gehandhaafd zou kunnen worden als deze geruchten een kern van waarheid bevatten. ${ }^{44}$

Het wekt dan geen verbazing dat de geheimzinnigheid rond de ss-smet door uitgerekend De Jong werd doorbroken. Hij vertolkte in de goed-fout discussie bij uitstek de 'absolute norm' uit de bezettingstijd: de strijdvaardige houding van geen enkele concessie aan de vijand die de illegaliteit had gekoesterd. De ss had het commando over de concentratiekampen gevoerd en daarmee symboliseerde dit meest gevreesde onderdeel van het nazi-regiem de moord op zes miljoen joden. Dit gegeven tartte ook de morele standaard van het Nederlandse volk. Mede naar aanleiding van De Jongs televisiedocumentaire DE BEZETTING 
(1960-1965) was er een schuldgevoel gegroeid dat uitgerekend in Nederland het hoogste percentage joden (het cijfer werd uiteindelijk vastgesteld op 75\%) was gedeporteerd van alle door de nazi's bezette West-Europese parlementaire democratieën. 45

\section{Het lek}

De zwijg-spreek spiraal werd op 6 november 1978 doorbroken door zowel de scoop van het Nieuwsblad van het Noorden als de persconferentie van De Jong. De uitkomsten van de beide geheime onderzoeksteams haakten in elkaar. Het verrassingseffect werd versterkt doordat het publiek in één dag van de inhoud van beide onderzoeken op de hoogte kwam.

Het RIOD-onderzoeksteam vond op woensdag I november documenten waaruit bleek dat Aantjes via de Waffen-ss in Hamburg was opgeroepen. De archiefvondst kwam geheel buiten het politieke en journalistieke circuit om tot stand en bracht het RIOD-onderzoek in een stroomversnelling. De Jong arrangeerde op donderdagmiddag 2 november een geheim overleg met premier Dries van Agt, de minister van Onderwijs, Kunsten \& Wetenschappen, Arie Pais - onder wie het RIOD ressorteerde - en de minister van Justitie, Job de Ruiter. Deze laatste bewindspersoon was aanwezig omdat de RIOD-onderzoekers vermoedden dat uit Aantjes' indiensttreding bij een vijandige organisatie mogelijkerwijze voortvloeide dat hij zijn Nederlanderschap had verloren.

Nog voordat de heren 's middags om drie uur in het Catshuis bijeenkwamen, ontstond er een lek, zonder dat de direct betrokkenen het zich realiseerden. Mevrouw De Jong belde aan het begin van de middag met haar broer in Assen, de gepensioneerde Henk Cost Budde, oud-griffier bij de Provinciale Staten van Drente. Zij liet hem weten dat zij en haar man helaas verhinderd waren voor zijn verjaardagsvisite. Loe was de laatste dagen verschrikkelijk druk met zo ongeveer de lastigste opdracht uit zijn loopbaan. Hij maakte die middag zijn opwachting in Den Haag voor topoverleg met de minister-president over Aantjes die zich in 1944 vrijwillig bij de ss had aangemeld. De terloopse uitwisseling over dit onderwerp duurde nog geen halve minuut.

Via welke bron dit nieuwtje uiteindelijk door het Nieuwsblad werd opgepikt, heeft de redactie van de krant succesvol weten af te schermen. Patijn concludeerde in I979 dat dit lek wel altijd het best bewaarde journalistieke geheim van Assen, Rolde en Groningen zou blijven..$^{6}$ Uit onderstaande reconstructie blijkt dat deze conclusie voorbarig was. 47

De zwager van De Jong was er niet van doordrongen dat hij over top secret beschikte. Cost Budde was voorzitter van de Provinciale Bibliotheek Centrale, die nog diezelfde middag vergaderde. Hij vertelde enkele vrienden en kennissen, terloops en mogelijk in vertrouwen, dat hij verwachtte dat dit 'nieuwtje van de eerste orde' nog diezelfde avond in het nieuws zou komen. Een van 
hen was de directeur van de Centrale, de heer C.A. de Kruif uit Rolde, die het nieuwtje na thuiskomst aan zijn vriend en achterbuurman doorvertelde. Deze Klaas Verbeek was voorzitter van de PvdA-afdeling Rolde. Nog diezelfde avond besprak hij met zijn fractievoorzitter, John Anema, over deze hoogst interessante ontwikkeling in politiek Den Haag. Anema had beloofd diezelfde avond Dirk van der Meulen, een van de vier verslaggevers van het Nieuwsblad van het Noorden voor de regio Assen, van de laatste ontwikkeling in de gemeentepolitiek op de hoogte te brengen. $\mathrm{Nu}$ hij hem toch aan de lijn had, gunde hij Van der Meulen - die hij als hardwerkende, nog jonge journalist waardeerde - dit geweldige nieuwtje dat heel Nederland op stelten zou zetten.

Omdat het al half twaalf in de avond was, besloot Van der Meulen om zijn chef Nieuwsdienst, Dick Dalmolen, die volgende ochtend als eerste te bellen. Dalmolen beloofde dit nieuws, waarvan het belang ver boven de lokale nieuwsberichtgeving uitsteeg, in het hoofdredactionele ochtendoverleg naar voren te brengen..$^{8}$ De krant wilde zich uiteraard geen canard op de hals halen en de eigen journalist als bron beschermen. Daarom werd de ervaren algemeen verslaggever, Theo Koopman, op de zaak gezet. 49 Koopman deed de hele vrijdag vergeefse pogingen om bij een aantal politici en mensen uit de kring rond De Jong inlichtingen te verkrijgen. Toen dit niets opleverde besloot hij, mede op advies van zijn collega, voormalig parlementair redacteur Kees Wiese, om De Jong recht op de man af met het gerucht te confronteren. Die avond belde Koopman De Jong voor het eerst op zijn thuisadres in Amsterdam, maar er werd niet opgenomen. Het hele weekend zou hij met de regelmaat van elk dagdeel bellen.

Van Agt had diezelfde vrijdagmiddag een in allerijl belegd gesprek tussen De Jong en Aantjes bijgewoond en hij had zonder opgaaf van redenen verstek laten gaan bij zijn wekelijkse televisiegesprek. Toen hij 's avonds laat terugkeerde in het Torentje, rook journalistiek Nederland onraad. De RvD-hoofddirecteur, Gijs van der Wiel, bezwoer Van Agt dat de geheimzinnigheid rond zijn agenda volgende week vrijdag in ieder geval uit de wereld moest zijn. De wildste speculaties deden de ronde, maar de naam van Aantjes werd vooralsnog niet genoemd. De Rijkswoordvoerder trachtte te voorkomen dat de Nos een item zou maken van een gerucht dat geen enkele realiteitswaarde had. 'Je mag me op het gezicht slaan als het niet juist is wat ik je nu adviseer,' zei hij, in een verwoede poging de situatie niet uit de hand te laten lopen. ${ }^{\circ}$

De Jong was een ervaren journalist met een uitstekend gevoel voor publiciteit. Hij was zich ervan bewust dat deze gevoelige kwestie in de pers een explosieve landing had. Hij vond het de hoogste tijd dat de politiek zich publiekelijk op basis van zijn RIOD-onderzoek een oordeel zou vellen over deze misstand. Het punt van het ss-lidmaatschap en het zwijgen hierover sinds I945 was weliswaar niet uitputtend, maar wel afdoende vastgesteld. Dat was ook de mening van Henk Dolk, met wie De Jong tijdens het onderzoeksproces van zondag 29 oktober tot en met zaterdag 4 november dagelijks contact onderhield. 
De ministers hadden zich nadrukkelijk niet inhoudelijk willen mengen in het oriënterend onderzoek van De Jong. Via een informant van Gerard Dolk kwam De Jong dat weekend in contact met de beide oud-kampgenoten die in I967 de getuigenis onder de aandacht van Berghuis hadden gebracht. Nadat hij hen had bezocht en hun verklaringen op papier had gezet, beschouwde hij zijn voorlopig onderzoek als afgerond. Zondagavond verwerkte hij de nieuwe gegevens in het eindrapport.

Rond tien uur 's avonds wist Theo Koopman van het Nieuwsblad van het Noorden De Jong eindelijk aan de lijn te krijgen. Kon De Jong bevestigen dat hij een onderzoek naar het ss-lidmaatschap van Aantjes deed en waren er schriftelijke bewijsstukken? De gesloten vraag bood geen ruimte voor een afleidingsmanoeuvre. De Jong antwoordde op dit moment geen verdere gegevens te kunnen verstrekken en verzocht de journalist om hem morgenochtend op zijn instituut terug te bellen..$^{\mathrm{I}}$ Koopman kreeg dus geen expliciet neen op zijn vraag en wist dat hij warm was. ${ }^{22}$

Die maandagochtend legden De Jong en zijn collega-onderzoeker, Hans (A.J.) van der Leeuw, de laatste hand aan het Aantjes-rapport. Toen Koopman belde verwees De Jong hem voor een toelichting naar de persconferentie die hij die avond zou houden. De journalist liet zich echter niet afschepen. Hij zinspeelde op het recht van de primeur in de journalistiek, waarbij het nieuws wordt gegund aan degene die de bron als eerste traceert. Uiteindelijk bevestigde De Jong dat hij 'in opdracht van de minister-president' een geheim onderzoek had ingesteld en dat 'de Aantjes-documenten voorhanden zijn'.53

De opwinding op de redactie was groot. Er restte nog anderhalf uur onderzoekstijd om dit nieuws uit andere kanalen bevestigd te krijgen. Vlak voor het zakken van de krant kreeg Kees Wiese, via tussenkomst van Berghuis, eindelijk Aantjes aan de lijn. De politicus gaf toe dat hij zich niet bij de Waffen-ss, maar bij de Germaanse-ss had aangemeld. Er viel een korte stilte. Aan weerszijden van de lijn drong het door dat dit onherroepelijk het einde van de politieke carrière van Aantjes betekende.54 Bevestiging bij de bron zette het sein voor publicatie op 'knalgroen'.55 Op de valreep werd de zeskoloms brede kop: 'Onderzoek RIOD naar oorlogsverleden Aantjes' vervangen door de eyecatcher: 'Aantjes meldde zich bij de ss'. In het hoofdredactionele commentaar werd een voorschot genomen op de politieke gevolgen: 'Een boeiende figuur zal spoedig afscheid nemen van het Binnenhof.'

\section{Een fraaie landing van de primeur in Hilversum}

$\mathrm{Nu}$ het nieuws op straat lag, was de ministers er alles aan gelegen om het RIODrapport zonder verder commentaar zo snel mogelijk door te geleiden naar de Tweede Kamervoorzitter. Aantjes werd om instemming met deze procedure gevraagd. In de consternatie overwoog hij niet om zich volledig te distantiëren 
van dit nog onvoldragen onderzoek. Zijn aandacht was erop gericht om eerst de ARP en CDA-top en vervolgens zijn CDA-fractie te informeren over zijn onherroepelijk besluit te zullen aftreden. De tijdrovende vergaderprocedure maakte geen schijn van kans tegenover de snelheid waarmee het publiek van het nieuws op de hoogte zou raken.

De Jong bracht op het ministeriële spoedberaad naar voren dat hij die avond, zoals gebruikelijk bij RIOD-rapportages, een persconferentie zou geven. Hij benadrukte voor alle duidelijkheid dat de politiek-staatsrechtelijke verantwoordelijkheid voor deze procedure vanzelfsprekend bij de ministers lag. Zij stemden er in alle haast mee in. Van Agt lichtte later toe dat hij dacht: 'Doe maar naïef, dan is het collectieve naïviteit. Een man van de reputatie, gezag en faam als De Jong zou dat doen op een klinische, zakelijke, gereserveerde manier zoals het een waarachtige wetenschapper betaamt. ${ }^{56} \mathrm{Om}$ vier uur verspreidde het ANP een interne RVD-aankondiging van de persconferentie van De Jong, zonder verdere toelichting.

Eef Brouwers ondernam die ochtend een poging om de primeur van zijn regionale blad zo eervol mogelijk in Hilversum te laten landen. Hij voorzag dat zijn regionale krant het initiatief in de berichtgeving zou kwijtraken aan de landelijke media. Nog voor het uitkomen van de eerste editie belde hij met Ed van Westerloo, de hoofdredacteur van het nos-journaal. In ruil voor vroegtijdige informatie en enkele uren zwijgplicht over nieuws dat Nederland op stelten zou zetten, kreeg Brouwers nadrukkelijke vermelding van zijn krant in de Nosberichtgeving. Halverwege het traject Groningen - Hilversum, ter hoogte van een benzinepomp bij 't Harde, ontmoette de chauffeur van een expeditieauto van het Nieuwsblad van het Noorden een motorkoerier van de Nos om de allereerste editie te overhandigen. Dit akkoordje tussen beiden heren, die elkaar goed kenden uit de tijd dat Brouwers als A-presentator het NOS-ACHTUURJOURNAAL presenteerde, slaagde perfect. ${ }^{57}$ Die middag hadden ze nog enkele keren telefonisch contact om elkaar over de laatste ontwikkelingen bij te praten..$^{8}$

Om II.30 uur verscheen de scoop op het telefaxcircuit van de GPD (Gemeenschappelijke Pers Dienst), waarop een groot aantal regionale kranten zoals het Nieuwsblad van het Noorden was aangesloten. Het ging vergezeld van het nadrukkelijke verzoek om het nieuws nog zo lang mogelijk exclusief binnen de eigen krantencombinatie te houden. Alleen de Gooi en Eemlander, die een late middageditie verzorgde, wist de primeur op de valreep nog op te nemen. Pas om half vijf verscheen het nieuws op de AN p-telex; net te laat voor de avondedities van de landelijke kranten. De 'Eigen nieuwsdienst', zoals de signatuur op de voorpagina van het Nieuwsblad luidde, had de landelijke pers afgetroefd. Dinsdagmiddag 7 november viel Eef Brouwers op de vergadering van het College van Hoofdredacteuren spontaan applaus ten deel toen de voorzitter met enige overdrijving sprak van 'de primeur van de eeuw'.59 Eef Brouwers verheugde zich in de 'fraaie, afgeronde primeur', waarmee de regionale krant geschiedenis schreef. De redactie had een eerste sneeuwvlokje te pakken gekregen, 
zo citeerde de GPD-columnist Nico Scheepmaker het primeur-proza van de hoofdredacteur. 'Dat hebben we gekoesterd en dat bleek een lawine te veroorzaken. ${ }^{60}$

De Nos-redactie laste die middag een late uitzending van DEN HAAG VANDAAG EXTRA in. Pas om vijf uur bracht het radiojournaal de nieuwstijding op Hilversum 3 met uitdrukkelijke bronvermelding van het Nieuwsblad. Een uur later was de NCRV-radio actualiteitenrubriek HIER \& NU geprogrammeerd. ${ }^{6 I}$ De voorpagina van het Nieuwsblad van het Noorden verscheen pontificaal op het scherm. De redactie genoot de twijfelachtige eer om, volstrekt onvoorbereid, als eerste verslag te mogen doen van de wankelmoedigheid van een christelijk geestverwant. Het radioprogramma opende met een fragment uit een interview uit juni 1976, waarin Aantjes vertelde hoe hij zich 'langs ingewikkelde wegen' aan zijn Duitse Arbeitseinsatz had weten te onttrekken. ${ }^{62}$ Daarna werden politici uit de eigen zuil aan het woord gelaten. Berghuis beaamde dat in 1967 binnen de ARP was afgesproken dat Aantjes in geen geval minister kon worden, omdat er anders 'een rel' zou uitbreken in het land. Van een ss-lidmaatschap wist hij zich echter niets te herinneren.

Daarna kwam Ben Sijes van het Riod aan het woord. Hij lichtte toe dat het hoogst ongebruikelijk was om op een 'dergelijke sluwe manier' een vluchtpoging naar Nederland via aanmelding bij de ss te ondernemen. Enkele dagen later bleek dat hij onwetend was geweest van een proces-verbaal uit een archief van de Publieke Recherche Afdeling (PRA), dat bij het Riod berustte. Hieruit werd duidelijk dat veel Nederlandse arbeiders, net zoals Aantjes, de Waffen-ss als vervoermiddel hadden gebruikt om naar hun moederland te vluchten. ${ }^{63}$

Van der Wiel had De Jong in de voorbespreking ontraden een live persconferentie voor de camera's te geven. ${ }^{64} \mathrm{Hij}$ wees op de televisiewerende regel die de RVD bij alle overheidsdepartementen hanteerde: persconferenties zijn voor de pers en niet voor de radio en televisie. Deze ervaringsregel was de beste remedie om ongewenste ruis en complicaties in de nieuwsspreiding te voorkomen. Alle bewindslieden conformeerden zich aan de standaardprocedure om de media beurtelings te bedienen, behalve in verkiezingstijd. Partijpropaganda vereist immers snelle profilering. ${ }^{65}$ Dat was precies wat De Jong beoogde. De RVD-waarschuwing voor het dreigende gevaar van de 'open buis' legde hij naast zich neer.

In de televisie Nos-bulletins van zeven en acht uur kreeg het item prominente aandacht. ${ }^{66}$ De kop van het Nieuwsblad van het Noorden verscheen in de volle breedte op het scherm. Beide journaals, waarin de persconferentie van De Jong later die avond werd aangekondigd, werden door zo'n 2.750.000 Nederlanders bekeken. ${ }^{67}$ Alle media-aandacht werd geleid naar de televisie, waarop De Jong de ware toedracht over dit schokkende nieuws uit de doeken zou doen.

Om kwart over acht deelde de RVD enkele tientallen exemplaren van het RIOD-rapport aan de journalisten uit. Zij hadden zich verzameld in de stampvolle, rokerige zaal van Nieuwspoort. De pers was een kwartier leestijd vergund. 
Toen De Jong even na half negen zijn persconferentie begon, citeerde hij niet letterlijk uit zijn rapport dat naast hem op tafel lag, maar sprak hij aan de hand van losse aantekeningen op zijn kladblok. Het grote publiek werd geïnformeerd via het gesproken woord.

\section{Dr. L. de Jong spreekt}

Hoewel De Jong de woorden in zijn onderzoeksrapport naar eigen zeggen had 'gewogen op een gouden weegschaal', registreerden de snorrende camera's in detail een betoog waarin Aantjes' oorlogsverleden op felle toon werd bekritiseerd. De in close-ups uitvergrote, sterk transpirerende De Jong bracht een aantal arbitraire veronderstellingen onder de aandacht. 'In alles wat de heer Aantjes tot dusver heeft meegedeeld, heeft hij, voor zover ons bekend, op wezenlijke punten verzwegen wat zich in bedoelde periode met hem heeft afgespeeld.' Later die avond zou De Jong zijn indruk nog eens bevestigen. Als het om zijn oorlogsverleden gaat zijn we 'geneigd geen enkele bewering van dhr. Aantjes voor waar te houden'. ${ }^{68}$

Feiten, veronderstellingen, voorbarige conclusies en meningen balden zich voor het oog van de verontwaardigde kijker samen tot een kernboodschap: Oudss'er Aantjes is een leugenaar! De Jong appelleerde aan de collectieve oorlogsherinneringen van de kijkers en het momentum was aan zijn zijde.

Niet alleen op de radio, ook op televisie was de NCRV die avond te zien met een extra editie van het NCRV-actualiteitenprogramma H IE R EN NU. Interviewer Hans Sleeuwenhoek was zichtbaar nerveus. Pikant detail was dat deze presentator in 1976 was benaderd door Henk Dolk over de pro-Duitse sympathieën van Aantjes tijdens de bezettingstijd. ${ }^{69}$ In het interview aansluitend op de persconferentie gaf De Jong een duidelijk signaal aan de christen-democraten: 'Ik kan mij geen ogenblik voorstellen dat wie ook op een verantwoordelijke post in de ARpartij of in het CDA, niet onmiddellijk consequenties zou hebben verbonden als dit feit aan de betrokkenen bekend was geraakt (...) De kruik gaat zo lang te water tot ze barst.' Ditmaal toonde Berghuis zich in zijn commentaar aanzienlijk strijdbaarder. Het was hem opgevallen dat 'De Jong wel erg fel voor de dag' was gekomen in zijn persconferentie. Zijn christelijke achterban vroeg hij deemoedig om begrip: 'Wie vrij van schuld is, werpe de eerste steen.' ${ }^{\circ}$

Televisierecensent Nico Scheepmaker observeerde hoe de NCRV in deze uitzen-

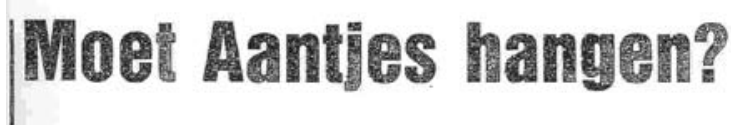

DOOR WILLEM ZUIDEMA

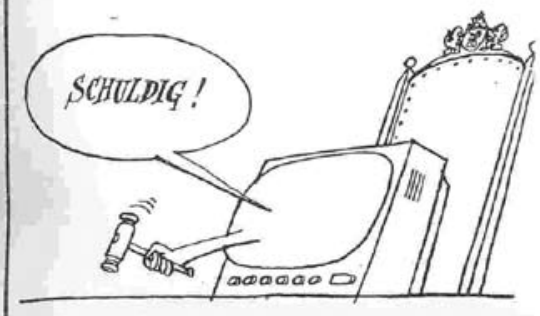

Hervormd Nederland 18 november 1978 
ding, die door bijna tweeënhalf miljoen televisiekijkers werd bekeken, was overvallen door het mediaoptreden van De Jong. De NCRv kon Aantjes deze avond niet als een rotte vrucht uit de mand met gave appelen opzij schuiven, schreef hij, maar in de chaotische en paniekerige sfeer was het evenmin veilig om zich over hem als verloren zoon te ontfermen..$^{7 \mathrm{r}}$

Even na 23.00 uur volgde op Nederland 2 de ingelaste uitzending van DEN haAG VANDAAG EXTRA..$^{72}$ Presentator Ton Planken had uit het CDA-kamp geluiden opgevangen dat 'de heer De Jong van het Rijksinstituut zo hard (oordeelde), die hield een requisitoir alsof hij de officier van Justitie was'. Daarom beperkte hij zich tot een samenvatting van het RIOD-rapport. Van De Jong nam hij over dat 'Aantjes waarschijnlijk geen Nederlander meer' is en op eigen gezag voegde hij er aan toe: 'de positie van Aantjes als fractieleider lijkt onhoudbaar geworden'. Vervolgens diste hij de informatie vakkundig in partjes op, afgewisseld door korte fragmenten van de persconferentie. 'Alsof het een TELEAC-cursus was,' zo evalueerde televisiecommentator Cor van der Poel de uitzending in de Leeuwarder Courant. 'Een beetje oplettende kijker moet het rapport bijkans uit zijn hoofd kennen.73 Samen met fragmenten in de late journaals was De Jong in drie verschillende programma's op de beeldbuis verschenen.74 In de mediahype die volgde werd De Jong verweten die avond te zijn opgetreden als 'snelrechter in vredestijd'.75

\section{Periodisering en typering van het schandaal}

Kort nadat de consternatie was uitgebroken vroeg NRC-commentator J.M. Bik zich af waarom 'wat in de loop van de jaren zestig en zeventig eigenlijk de kwestie-Aantjes was, maar nog niet zo heette' niet eerder tot een ontknoping was gekomen. ${ }^{6}$ Het antwoord op zijn vraag is gelegen in de hierboven geschetste decennialange voorgeschiedenis van zwijgen en spreken. Vanuit dit langetermijnperspectief was het etmaal van 6 op 7 november 1978 waarin de publieke opinie zich tegen Aantjes keerde en hij abdiceerde niet alleen het hoogtepunt van het schandaal, maar ook het topje van de ijsberg waarover de pers pas voor het eerst berichtte. De affaire-Aantjes kwam niet tot een einde in het slotdebat van eind augustus I979. De tien voorafgaande maanden kunnen worden aangemerkt als het procedural scandal, waarin het schandaal politiek-procedureel werd afgehandeld. Maar het substantive scandal, de inhoudelijke kant van de zaak, was al bij de kandidaatstelling van Aantjes in 1956/'57 begonnen, of moet eigenlijk worden gedateerd vanaf de bevrijding in april 1945 , toen Aantjes besloot om over zijn contact met de ss het zwijgen toe te doen. Na 1979 hield de evaluatie van het schandaal nog ruim twee decennia aan. ${ }^{77}$

Aantjes is altijd van mening gebleven dat zijn opstelling in de oorlog persoonlijk te verdedigen is. Omdat hij er altijd van doordrongen was dat, zodra de ss wordt genoemd, de emoties de overhand zouden krijgen, had hij over 
zijn oorlogsverleden alleen de feiten verteld en de letters verzwegen. Daarom had hij nog niet gelogen. Hij meent de goede zaak niet te hebben geschaad en de slechte niet gediend. In tegenstelling tot de verderfelijke ss waren zijn intenties niet kwaad. Bij aankomst in Nederland was hij 'in zekere zin ook een dienstweigeraar' geweest, zoals Lubbers, die het opnam voor zijn partijgenoot, het geformuleerd had. ${ }^{8} \mathrm{Al}$ zouden zijn persoonlijke overwegingen in de private levenssfeer te billijken zijn, in het publieke domein schond hij het vertrouwen dat hij als politicus had opgebouwd. Het overtuigt dan ook niet dat Aantjes in 2005 te kennen gaf dat hij bij de aanvaarding van het fractievoorzitterschap zijn ss-vlucht openhartig in de publiciteit had kunnen brengen om zich van zijn belemmering te bevrijden. ${ }^{79}$ Ook zijn voorstanders zouden hun lot niet hebben willen verbinden aan een Aantjes die over zijn ss-affiliatie sinds I945 had gezwegen. Het kwaad kleefde hem aan.

Volgens de gangbare definitie van een politiek schandaal was zijn val onvermijdelijk:

'A scandal creates a perplexity of conscience occasioned by the conduct of one who is looked up to as an example. It is not the conduct itself but its relation to a public role and the attendant expectations of that role which matter.' 80

De affaire Aantjes is een institutional scandal, waarbij de persoonlijke overtuiging van de politicus botste met de heersende morele standaard. 'Their indiscretions become scandalous because these persons represent not only themselves, but the institutions in which they are professionally situated. ${ }^{8 \mathrm{I}}$

Bij het uitbreken van het schandaal speelden de barrières in de politiekjournalistieke cultuur die ervoor hadden gezorgd dat het nieuws over de ss langdurig afgeschermd was gebleven, geen rol meer. De commotie leidde tot een kortstondige intensiverende mediahype. De persconferentie van Loe de Jong was de sleutelgebeurtenis (key event) en de mediahype hield, vooral ook door het Kamerdebat van donderdag i 6 november, aan tot en met zaterdag I8 november I978, als in de opiniebladen het schandaal opnieuw uitgebreid wordt besproken. $\mathrm{Na}$ twee weken was de mediaype, in overeenstemming met het verloop van de issue attention cycle, geluwd tot normale proporties. ${ }^{82}$

Het schandaal ijlde in de media echter nog een kwarteeuw na. De affaire bleef een hot item, waarbij de berichtgeving synchroon liep met de feitelijke ontwikkelingen. De politiek had binnen enkele dagen de regie weer in handen. Het tempo werd aangegeven door de beide onderzoekscommissies, bij wie het primaat berustte om zich over de juiste toedracht te mogen buigen. Zij verkozen om de pers buiten de deur te houden tot het moment dat zij beide hun rapporten presenteerden. Vanaf eind november I978 kan gesproken worden van enkele reflecterende nieuwsgolven, die piekten rond 22 juni i979 toen de commissierapporten uitkwamen en rond het Tweede Kamer slotdebat eind augustus I979. 
De onderzoeksresultaten van beide commissies bleken robuust en de pers heeft sindsdien geen nieuw licht meer op de zaak kunnen werpen. Vanwege de destijds explosieve inhoud dook de herinnering aan het schandaal in de media echter ieder keer weer op zodra betrokkenen, vooral Aantjes zelf, uitlatingen deden. De televisie bleef het favoriete medium waarop het langdurige nakaarten over de affaire-Aantjes zich voor het publiek afspeelde. De laatste twee hoogtepunten waren het Nos-programma BUITENHOF op Paaszondag I999, waarin Aantjes en Van Agt zich verzoenden en het VARA-programma HET ZWARTE SCHAAP op I9 januari 200I. Presentatrice Inge Diepman kreeg er de Academy Award voor toegekend.

In HET ZWARTE SCHAAP waren bijna alle kopstukken verenigd. De oude verschillen van mening prevaleerden en nieuwe inzichten waren er niet. Voormalig minister Pais bracht opnieuw de maatschappelijke commotie in herinnering die het zittende kabinet-Van Agt-Wiegel in het nauw had gebracht. Hij nam het woord complot niet in de mond, maar volgens hem was 'het geen toeval' dat Aantjes juist op dat moment was gevallen. Ed van Thijn, die in 1978 PvdA-vice-fractievoorzitter was, repliceerde nijdig dat deze gedachtegang van een 'perverse geest' getuigde. Pais bleef met een strak gezicht onverzettelijk voor zich uit staren. Hans van der Leeuw vertegenwoordigde De Jong, die zich wegens gezondheidsredenen had verontschuldigd. Sinds het overlijden van De Jong in 2005 lijkt het erop dat de affaire-Aantjes in de eerste jaren na de eeuwwisseling definitief tot een einde is gekomen.

\section{Slot}

Veel meer nog dan zijn 'vlucht via de ss' werd Aantjes als publieke figuur zijn systematisch zwijgen hierover aangerekend. Op zijn persconferentie in 1979 was Aantjes hierover duidelijk: 'Als ik daarover - het verzwijgen - ben gestruikeld is dat terecht. ${ }^{83}$ Toen Aantjes in 1959 Kamerlid werd, was in de maatschappelijke mentaliteit en zijn persoonlijke beleving niet te voorzien dat dit incident uit zijn oorlogsverleden in de publieke opinie tot een politiek schandaal zou uitgroeien. Gedurende dit eerste decennium was het zwijgen vanzelfsprekend en bleef het spreken beperkt tot een enkel incident. Op 3I maart I967 voltrok zich een felle botsing in de zwijg-spreek spiraal. Om een ontknoping te voorkomen kwam tussen Aantjes en de ARP-top een gelegenheidsoplossing tot stand die buiten de publiciteit kon worden gehouden. Het resulteerde in de demarcatielijn dat Aantjes wel volksvertegenwoordiger mocht blijven, maar geen minister mocht worden.

Eind jaren zestig groeide Aantjes uit tot een populaire politicus. In de gepolariseerde jaren zeventig werd Aantjes in de linkse politieke cultuur gespaard, omdat hij als potentieel medestander werd bejegend en niet tot het kamp van de rechtse politici werd gerekend. Ongebonden waarheidsvinding onder jour- 


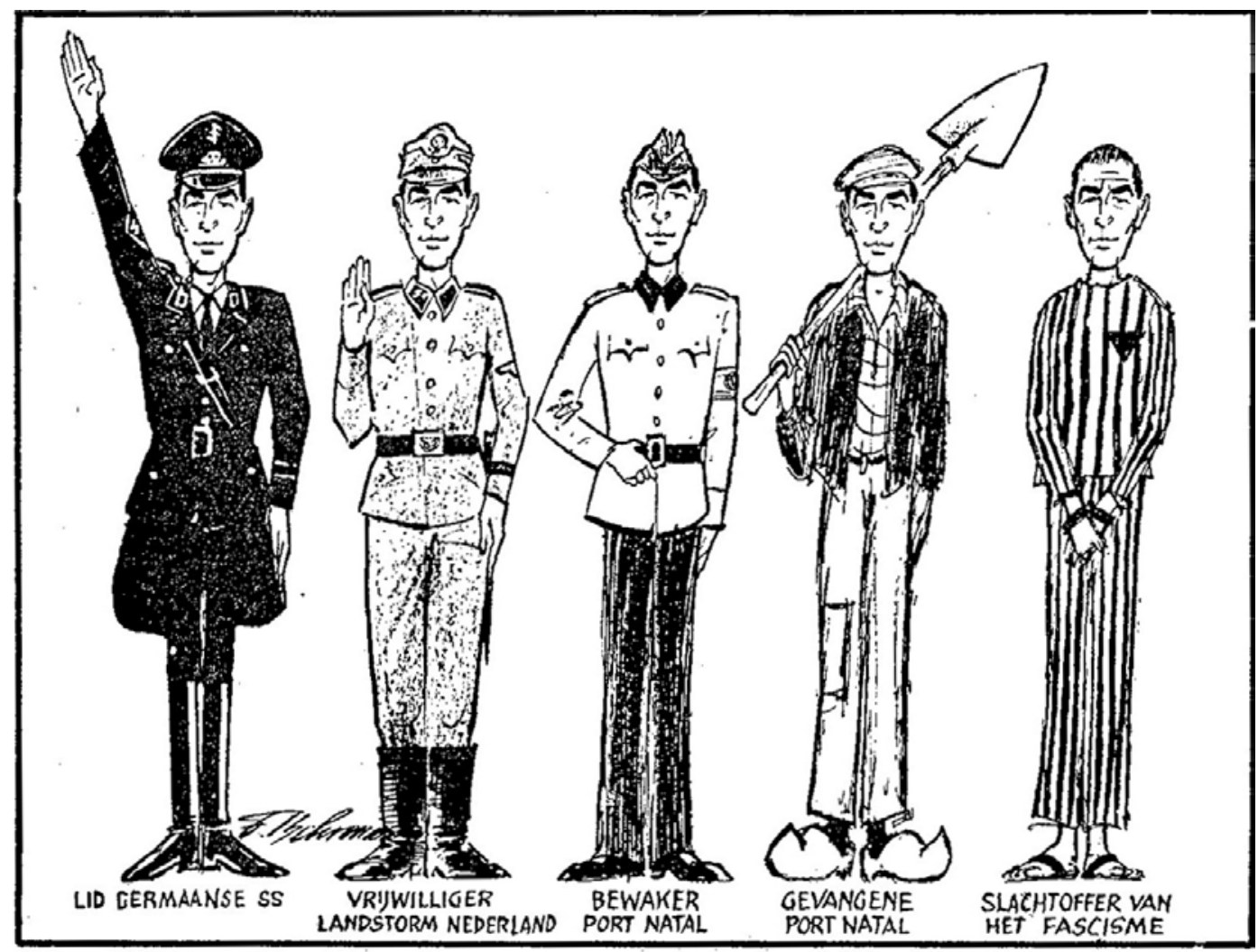

Etiketten voor Aantjes

Fritz Behrendt in Het Parool 30 augustus 1979

nalisten brak slechts geleidelijk door. Ondanks pogingen van journalisten om hardnekkige geruchten te ontwarren, bleek de afscherming van de ARP-politici die erbij betrokken waren en de integriteit die Aantjes als 'handelsmerk aankleefde, voldoende om opdringerige vragen selectief af te weren.

De doorbraak in de zwijg-spreek spiraal kwam dan ook uit de hoek van een onafhankelijk specialist, L. de Jong. Het onderzoek van de RIOD-directeur maakte geen deel uit van een complot, al was De Jong op het spoor gezet door enkele advocaten uit de rechts-conservatieve hoek die al twintig jaar lang de geruchtenmachine voedden. In de publieke opinie werd binnen een etmaal afgerekend met een gedateerde, typisch verzuilde oplossing van een oorlogserfenis.

Het verrassingselement school ook in de kortstondig eenzijdige manier waarop het publiek kennis nam van het nieuws. De scoop van het Nieuwsblad van het Noorden had tot gevolg dat het RIOD-onderzoek in een prematuur stadium in de schijnwerpers kwam te staan. De nos-televisie creëerde een tweede, nationale primeur in ruil voor maximale exposure van het Nieuwsblad van het 
Noorden. De samenwerking achter de schermen tussen een regionale krant en de landelijke televisie bleek effectief. De landelijke dagbladen visten achter het net en de journalisten van de NCRV werden volkomen verrast.

Door dit overrompelingseffect ontbrak een strakke politieke regie. Het politieke schandaal werd een mediahype. Via de televisie kwam een verbijsterend snelle verspreiding van dit schokkende nieuws tot stand. Niet de voorzitter van de Tweede Kamer, Anne Vondeling, de minister-president, Dries van Agt, of het Kamerlid Willem Aantjes zelf, sprak het Nederlandse volk toe, maar de wetenschapper Loe de Jong. De verwarring bij het publiek was groot toen naderhand bleek dat hij slechts voorlopige resultaten had toegelicht. De onvolkomenheden in het RIOD-rapport werden uitvergroot. Van een onafhankelijke onderzoeker verwachtte men uitsluitsel en geen voorbarige veronderstellingen. Het mechanisme van zwijgen en spreken, waarop de pers decennialang geen vat had gekregen, vond zijn tegenhanger in de kortstondige mediahype.

\section{Noten}

I De auteur van dit artikel bereidt een biografie voor van Loe de Jong. De dissertatie wordt begeleid door prof. dr. H. Renders (Biografie Instituut/Rijksuniversiteit Groningen), prof. (em.) dr. J.C.H. Blom en prof. dr. P. Romijn (N Iod /Universiteit van Amsterdam). Zie: www.rug.nl/let/ onderzoek/onderzoekcentra/biografieinstituut/biografieloedejong.

2 Radioprogramma AVRo's RADio journAAL dinsdag 7 november I978, Hilversum I, I3.00 uur.

3 Op radio en televisie werd aan de affaire-Aantjes naar schatting rond de 40 uur uitzendtijd gewijd. De programma's, voor zover bewaard gebleven, zijn te raadplegen in het Nederlands Instituut voor Beeld en Geluid (N IBG/Beeld \& Geluid), Mediapark in Hilversum.

4 Het RVD-publiciteitsoverzicht bevat alle artikelen (2.340 bladzijden) over de affaire-Aantjes die van 6 november I978 t/m I3 sept. I979 zijn verschenen. Een ruwe schatting is dat er ruim 2.000 artikelen in de Nederlandse dag-, week- en maandbladen over dit schandaal zijn verschenen. De artikelen zijn onder meer te raadplegen in het NIOD in Amsterdam: Knipselkrant Aantjes, кв I 10760.

5 Handelingen van de Tweede Kamer der Staten-Generaal, zitting I978-1979. Rapport van de Commissie van Drie in de zaak-Aantjes. Bijlagen I5625, nr. I en 2. Aangeboden op I4 juni I979.

6 Handelingen van de Tweede Kamer der Staten-Generaal, zitting I978-I979. Rapport van de Bijzondere Kamercommissie van onderzoek naar kennis omtrent de gedragingen van mr. W. Aantjes tijdens de Tweede Wereldoorlog. Bijlagen I5626, nr. I en 2. Aangeboden op I4 juni i979. De Commissie hoorde 57 getuigen die sinds I945 mogelijk op de hoogte waren geweest van Aantjes' oorlogsverleden.

7 Handelingen Tweede Kamer, zitting I978-1979, 29 augustus I979, p. 5996.

8 Telefoongesprek met Schelto Patijn door Boudewijn Smits, 28 maart 2007.

9 Handelingen Tweede Kamer, I978-1979, I5626 (rapport Bijzondere Kamercommissie), nr. 2, Interview K. Wiese, p. 57. Interview E. Brouwers, p. 39, 45 en 48.

Io Handelingen Tweede Kamer, I978-1979, I5626 (rapport Bijzondere Kamercommissie), nr. 2, Interview L. van Heijningen, p. 274-275. Idem, Interview Iwan Hes, p. 263-267. Idem, Interview Piet Los op II mei I979, p. 592-59I. Idem, Interview Henk Dolk, p. 348 en 354.

II Brief van Gerard Dolk aan de Voorzitter van de Tweede Kamer, I5 november I978. NIOD: 700, correspondentiearchief, I978, doos: Aantjes A-D. 
I2 Telefoongesprek met Thomas Lepeltak (alias Stan Huygens) door Boudewijn Smits, 22 maart 2007.

I3 Henk de Mari en Kees van der Wild, [Reportage], De Telegraaf, in november i978. Henk Hofland, 'De verklikkers', Haagse Post, I8 november i978.

I4 Handelingen Tweede Kamer, I978-I979, I5626 (rapport Bijzondere Kamercommissie), nr. 2, Interview Thomas Lepeltak, p. 88. Idem: Interview Loe de Jong, p. 34.

i5 VPRo-radioprogramma Welingelichte KRINGEN, IO november I978, Hilversum 2.

I6 Wessel-Tuinstra ontleende het 'zwijgcomplot' aan een artikel uit de Leeuwarder Courant, 23 juni I979.

I7 Handelingen Tweede Kamer, zitting I979-I980, 29 augustus I979, p. 5983.

I8 N. Elias, Het civilisatieproces. Sociogenetische en psychogenetische onderzoekingen, Utrecht/ Antwerpen I982, p. 240-242. J. Goudsblom, De sociologie van Norbert Elias, weerklank en kritiek. De civilisatietheorie, Amsterdam i987, p. 35-38.

I9 Handelingen Tweede Kamer, I978-I979, I5626 (rapport Bijzondere Kamercommissie), Interview George Puchinger, nr. 2, p. I42, I46, I51. Handelingen Tweede Kamer, zitting I979-1980, 30 augustus I979, spreektijd Joop Voogd, p. 6oIo.

20 R. Bouwman, De val van een bergredenaar. Het politieke leven van Willem Aantjes, Amsterdam 2002, p. 86-88 en 93.

2I Bouwman, De val van een bergredenaar, p. IIO-III.

22 Bouwman, De val van een bergredenaar, p. II4, II6 en I23. Aantjes wist zich niet herinneren van Dolk een telegram te hebben ontvangen. Handelingen Tweede Kamer, I978-1979, I5626 (rapport Bijzondere Kamercommissie), nr. 2, Interview Willem Aantjes, p. 630.

23 Bouwman, De val van een bergredenaar, p. I25. Deze beide schriftelijke getuigenissen van J. Mastebroek en A. Weites, die gedateerd moeten zijn geweest op 30 of 3I maart I967, zijn nergens te traceren. De getuigenissen die De Jong hen opnieuw liet afleggen op zaterdag 4 en zondag 5 november I978 zijn opgenomen in zijn rapport van 6 november I978. Handelingen Tweede Kamer, I978-I979, I5364, nr. 2. 'Enkele gedragingen van mr. Willem Aantjes gedurende de periode van de Duitse bezetting, I940-I945' door L. de Jong en A.J. van der Leeuw, maandag 6 november I978, p. I6 en I7.

24 Handelingen Tweede Kamer, I978-1979, I5626 (rapport Bijzondere Kamercommissie), nr. 2, Interview Wiert Berghuis, p. 65. Idem, Interview Willem Aantjes, p. 629.

25 J.W. Brouwer \& J. van Merriënboer, Van buitengaats naar Binnenhof, P.J.S. de Jong, een biografie, Den Haag 2002, p. I06-I07 en noot 3I, p. 528. Aantjes meende het gesprek met Piet de Jong op een later tijdstip te hebben gehad. Handelingen Tweede Kamer, I978-1979, I5626 (rapport Bijzondere Kamercommissie), nr. 2, Interview Aantjes, p. 630-63r. Hier worden de bronnen van Brouwer/van Merriënboer aangehouden, die zijn gebaseerd op de aantekeningen van de Kabinetsformatie op 3I maart I967 van formateur Piet de Jong.

26 Handelingen Tweede Kamer, I978-1979, I5626 (rapport Bijzondere Kamercommissie), nr. I, p. I7.

27 Handelingen Tweede Kamer, I978-1979, ${ }_{5} 626$ (rapport Bijzondere Kamercommissie), nr. 2, Interview Henk Dolk, p. 35I en 358.

28 Interview met Willem Aantjes door Boudewijn Smits, 4 april 2007.

29 Handelingen Tweede Kamer, I978-1979, ${ }_{5} 626$ (rapport Bijzondere Kamercommissie), nr. 2, Interview Wiert Berghuis, p. 66-67 en 69. Idem: Interview Willem Aantjes, p. 635.

30 Berghuis, Smallenbroek, Bruins Slot en Bakker zijn allen overleden. Of zij werkelijk wisten dat de ss bij de vlucht van Aantjes in het geding was, kan niet meer worden achterhaald.

3I Bouwman, De val van een bergredenaar, p. I27-I30 en I33.

32 I. van den Broek, 'Engagement als deugd, politieke journalistiek tijdens het kabinet-Den Uyl', in: J. Bardoel et al. (red.), Journalistieke cultuur in Nederland, Amsterdam 2002, p. 68-82, p. 72.

33 VPRo-Radioprogramma WELINGELICHTE KRINGEN, IO november I978, Hilversum 2.

34 Bouwman, De val van een bergredenaar, p. 227

35 Nps-televisieprogramma BUITENHOF, 4 april I999. 
36 E.H. Kossmann, 'Continuïteit en discontinuïteit in de naoorlogse geschiedenis van Nederland', in: Ons Erfdeel 28 (I985) 5, p. 659-668, p. 667.

37 Bouwman, De val van een bergredenaar, p. 229.

38 I. van den Broek, 'Engagement als deugd', p. 68-82, p. 69, 70 en 76.

39 Handelingen Tweede Kamer, I978-I979, I5626 (rapport Bijzondere Kamercommissie), nr. 2, Interview Henk Dolk, p. 353. Idem: Interview Harry van Wijnen, p. 535 en 539-540. Bouwman, De val van een bergredenaar, p. 225 en 229.

40 Handelingen Tweede Kamer, I978-I979, I5626 (rapport Bijzondere Kamercommissie), nr. 2, Interview Harry van Wijnen, p. 539.

4I Handelingen Tweede Kamer, I978-I979, I5626 (rapport Bijzondere Kamercommissie), nr. 2, Interview Harry van Wijnen, p. 537-540. Idem: Interview George Puchinger, p. I40. Bouwman, De val van een bergredenaar, p. 30I.

42 Interview met Willem Aantjes door Boudewijn Smits, 4 april 2007.

43 R. Grüter, Een fantast schrijft geschiedenis, de affaire rond Friedrich Weinreb, Balans Amsterdam I997, onder meer blz. I4I-I43.

44 Handelingen Tweede Kamer, I978-1979, 15626 (rapport Bijzondere Kamercommissie), nr. 2, Interview Loe de Jong, p. 469, 470, 472 en 479.

45 J.C.H. Blom, 'De vervolging van de joden in Nederland in internationaal perspectief', in: J.C.H. Blom, Crisis, bezetting en herstel: tien studies over Nederland 1930-1950, Den Haag I989, p. I34I50, p. I34, I36.

46 Handelingen Tweede Kamer, I978-I979, I5626 (rapport Bijzondere Kamercommissie), nr. I, p. 26 en 28. Nr. 2, Interview Henk Cost Budde, p. 398-399. Idem: Interview Loe de Jong, p. 32.

47 Telefoongesprek met Dirk van der Meulen door Boudewijn Smits, 22 juni 2007. Met bijzondere dank aan Dirk van der Meulen, wiens naam ik na veelvuldige pogingen wist te traceren. Hij was zo bereidwillig om de gebeurtenissen over zijn gouden tip drie decennia na dato alsnog uit de doeken te doen, waarbij hij kon putten uit zijn zorgvuldig bijgehouden logboekaantekeningen.

48 Telefoongesprek met Dick Dalmolen door Boudewijn Smits, 26 maart 2007.

49 Telefoongesprek met Theo Koopman door Boudewijn Smits, 27 maart 2007.

50 Handelingen Tweede Kamer, I978-I979, 15626 (rapport Bijzondere Kamercommissie), nr. 2, Interview Gijs van der Wiel, p. 434, 438-439. 'Zorgvuldigheid', [anoniem], Nederlands Dagblad, 20 november i978.

5I Handelingen Tweede Kamer, I978-I979, I5626 (rapport Bijzondere Kamercommissie), nr. 2, Interview Loe de Jong, p. 28, 505, 503 en 507. Idem: Interview Eef Brouwers, p. 4I. Idem: Interview Kees Wiese, p. 54 .

52 Gerdt van Hofslot, 'De weegschaal van Loe de Jong', Nieuwsblad van het Noorden, I9 maart 2003.

53 'Aantjes meldde zich bij de ss', Nieuwsblad van het Noorden, 6 november I978. Handelingen Tweede Kamer, I978-I979, 15626 (rapport Bijzondere Kamercommissie), nr. 2, Interview Kees Wiese, p. 54. Idem: Interview Eef Bouwers, p. 44.

54 Telefoongesprek met Kees Wiese door Boudewijn Smits, 26 maart 2007.

55 Handelingen Tweede Kamer, I978-1979, 15626 (rapport Bijzondere Kamercommissie), nr. 2, Interview Eef Brouwers, p. 44.

56 VARA-Televisieprogramma HET ZWARTE SCHAAP, I9 januari 200 I.

57 Voor de status van A-presentator, zie: A. van Liempt, Het Journaal, 50 jaar achter de schermen van het nieuws, Amsterdam 2005, p. I69.

58 Telefoongesprek met Eef Brouwers door Boudewijn Smits, 27 maart 2007.

59 Brief van Eef Brouwers aan Dirk van der Meulen, 9 november I978. Particulier archief D. van der Meulen.

60 Nico Scheepmaker, GPD-televisierubriek 'Trijfel', Nieuwsblad van Noorden, 9 november 1978.

6ı.Handelingen Tweede Kamer, I978-1979, I6 november I978, p. I466. 
62 Presentatrice Noortje van Oostveen lichtte toe dat deze passage was uitgezonden door Veronica televisie in juni 1976 - in het radio actualiteitenprogramma-NCRV HIER EN NU, even na I8.00 u.

63 [Anoniem], 'Nieuw gevonden document onthult: veel arbeiders vluchtten uit Duitsland via de ss', Het Binnenhof, I5 november 1978 .

64 Handelingen Tweede Kamer, I978-1979, 15626 (rapport Bijzondere Kamercommissie), nr. 2, Interview Loe de Jong, p. 487 en 488. Idem: Interview Dries van Agt, p. 576. Prof. F. Duynstee, 'Mr. W. Aantjes', De Telegraaf, maandag I3 november 1978.

65 Harry van Wijnen, 'De Jong onderschatte tv', Het Parool, 9 november 1978.

66 Handelingen Tweede Kamer, I978-1979, I6 november 1978, p. I466. De nos-journaAL uitzendingen zijn niet bewaard gebleven.

67 Nos-Informatie centrum, Afdeling Kijk- en Luisteronderzoek. De Kijkdichtheid (KDH) was $25 \%$. De hoogste KDH voor het journaal in dat kwartaal bedroeg 37\% op 2I november 1978 .

68 NCRv-televisie programma HIER EN NU EXTRA 6 november I978, 20.35 uur, Nederland I.

69 Handelingen Tweede Kamer, 1978-1979, 15626 (rapport Bijzondere Kamercommissie), nr. 2, Interview Henk Dolk, p. 354.

70 NCRV-tv programma HIER \& NU 6 november 1978, 2I.45 uur, Nederland 2. Het programma werd door $2.420 .000(22 \% \mathrm{KDH})$ televisiekijkers bekeken.

7I Nico Scheepmaker, 'Aantjes en de televisie', Gooi- en Eemlander, zaterdag in november 1978.

72 Nico Scheepmaker, 'De affaire Aantjes op de televisie', Haagsche Courant, maandag I3 november I978. Omdat dit programma was ingelast, zijn er geen kijk \& luistercijfers over beschikbaar.

73 Cor van der Poel, 'Teleac-cursus van Den Haag Vandaag', Leeuwarder Courant, dinsdag 7 november 1978 .

74 Wim Kock, 'Wim Aantjes, de vernietiging van een levenswerk', De Stem, 9 november 1978. F.W. Grosheide, 'Diensten aan de vijand zijn niet altijd staatsdiensten', NRC Handelsblad, Io november I978. Bouwman, De val van een bergredenaar, p. 320.

75 Handelingen Tweede Kamer, donderdag I6 november I978, p. I454.

76 J.M. Bik, 'Discussie met een verbazend verloop', NRC Handelsblad, I5 november 1978.

77 R. Williams, Political scandals in the USA, Edinburgh, 1998, p. 8. De terminologie is van Theodore J. Lowi.

78 Handelingen Tweede Kamer, zitting I978-1979, I4-I6 november I978, p. I453-I458; zitting I979-1980, 29 augustus 1979, p. 5979.

79 Interview met Aantjes, in: P. Siebe (red.), Brieven aan God, Kampen 2005, p. 93.

80 Williams, Political scandals in the USA, p. 6. De definitie is afkomstig uit de Shorter Oxford dictionary.

8I J. Lull \& S. Hinerman (ed.), Media Scandals: morality and desire in the popular culture marketplace, Cambridge I997, p. 20.

82 P. Vasterman, Mediayhype, Amsterdam 2004, p. 240-242. Vasterman definieert mediahype als 'een mediabrede, snel piekende nieuwsgolf die één gebeurtenis als startpunt heeft en die voor het grootste deel het gevolg is van zichzelf versterkende processen binnen de nieuwsproductie'.

83 Handelingen Tweede Kamer, zitting I978-I979, 29 augustus I979, p. 5975. 